\title{
DEVELOPMENT OF IRRIGATION TANK MONITORING SYSTEM AND ITS ENVIRONMENT FOR THE EFFECTIVENESS OF RICE IRRIGATION
}

\author{
Dewi Sartika T. ${ }^{1}$, Rico Sihotang ${ }^{1}$, Muhamad Muslih², Agustami Sitorus 3 , \\ Oscar Haris ${ }^{4}$, Devianty ${ }^{5}$, Ramayanty Bulan ${ }^{5}$ \\ ${ }^{1}$ Department of Civil Engineering, Nusa Putra University, Jl. Raya Cibatu Cisaat No. 21, Sukabumi, West Java, \\ 43155, Indonesia \\ ${ }^{2}$ Department of Information System, Nusa Putra University, Jl. Raya Cibatu Cisaat No. 21, Sukabumi, West Java, \\ 43155, Indonesia \\ ${ }^{3}$ Research Center for Appropriate Technology, Indonesian Institute of Sciences, Jl. Ks. Tubun No. 5, Subang, West \\ Java, 41213, Indonesia \\ ${ }^{4}$ Department of Mechanical Engineering, Nusa Putra University, Jl. Raya Cibatu Cisaat No. 21, Sukabumi, West \\ Java, 43155, Indonesia \\ ${ }^{5}$ Department of Agriculture Engineering, Faculty of Agriculture, Syiah Kuala University, Jl. Teuku Nyak Arief, \\ Kopelma Darussalam, Banda Aceh, Aceh, 23111, Indonesia
}

Link to this article: https://doi.org/10.11118/actaun202068050859

Received: 18. 12. 2019, Accepted: 28. 8. 2020

To cite this article: SARTIKA T. DEWI, SIHOTANG RICO, MUSLIH MUHAMAD, SITORUS AGUSTAMI, HARIS OSCAR, DEVIANTY, BULAN RAMAYANTY. 2020. Development of Irrigation Tank Monitoring System and Its Environment for the Effectiveness of Rice Irrigation. Acta Universitatis Agriculturae et Silviculturae Mendelianae Brunensis, 68(5): 859-865.

\begin{abstract}
The SRI (system of rice intensification) rice cultivation system can save water use and increase production. Besides, a controlled environment for monitoring such matters is important to be recorded to be able to investigate deeply the phenomena that occur. Therefore, a preliminary test to analyze the performance of the irrigation tank monitoring system and its environment was developed to monitor the effectiveness of rice cultivation watering at the research stage. A $400 \mathrm{~mm} \times 700 \mathrm{~mm}$ bed planting fruit will be planted with water from two tanks with a $0.03 \mathrm{~m}^{3}$ capacity. A bed planting and tank were designed for two conditions, namely automatic and manual bed planting and tank. The control box of the monitoring system is placed in the water tank by monitoring water level, ambient temperature and humidity, water temperature, and illuminance from light. The performance test results of the monitoring system show that the device can function within normal limits. Sensors integrated with the ESP8266 NodeMCU development kit can be to record environmental conditions. The measurement data is then sent to the cloud via the internet and stored as a database. This database can be easily downloaded for further analysis if needed.
\end{abstract}

Keyword: SRI, paddy, IoT, bed planting, microcontroller

\section{INTRODUCTION}

Rice is the main food crop in Asia, so its production is still being investigated to be improved (Paudel et al., 2019; Padhi, 2019; Pattnaik et al., 2020). On the one hand, the rice system in the fields requires a lot of water in cultivation (Carracelas et al., 2019). Rice planting media must always be flooded from land preparation, planting to harvest. On the other hand, the availability of water is increasingly limited due to various things. Therefore, researchers continue to look for ways to be able to conserve water used for lowland rice cultivation. 
Many methods have been explored to be able to conserve water use in lowland rice cultivation. Singh et al. (2016) and Thakur et al. (2018) conducted research by developing rice varieties that consumed little water but remained high in productivity. This solution is the long-term sustainability of rice cultivation, which is still being sought to be found. At the stage of land preparation, Cebro and Sitorus (2019) study demonstrated the improvement of equipment in tillage so that it can streamline time and ultimately save water use at the stage of land preparation. At the stage of cultivation, the development of a method of providing water following the stage of the growth of rice plants as carried out by Boonjung and Fukai (1996) and Zhang et al. (2019). The results of his research report that this method of administration can save water use and can increase rice production produced. However, this has not been confirmed again by knowing other effects such as environmental conditions, soil, and the type of variety used.

Information on the environmental conditions of rice cultivation is crucial to be able to answer the research challenges above. Physical environmental conditions such as temperature, relative humidity, water temperature, and illuminance from sunlight play a role in the photosynthesis process, which should also be monitored in the study. These efforts are often constrained by expensive scientific measurement instrumentation so that researchers often ignore the recording process. A system that can monitor the irrigation tank and the environment was developed to be able to monitor the condition of the environment. Therefore, this paper presents results of the functional performance of the tank monitoring system and its environment for the effectiveness of rice irrigation.

\section{MATERIALS AND METHODS}

\section{Description of Irrigation Tank}

The irrigation tank that can be monitored in environmental conditions is a container to be able to hold a certain amount of water. The water is collected to facilitate the delivery of water to bed planting. The monitoring system aims to be able to monitor the condition of the irrigation water tank and the surrounding environment before it is given to the plants. As needed, the volume of the designed irrigation water tank has a capacity of $0.03 \mathrm{~m}^{3}$. The water tank is placed $500 \mathrm{~mm}$ from the ground. The water tank is equipped with a lid and valve system so that the fluid can freely flow and not be contaminated directly with the environment.

\section{Description of the System Monitoring}

The irrigation tank monitoring system and its environment are equipped with several sensors and a microcontroller (Fig. 1). Digital DHT22 sensor is used to measure temperature and humidity around irrigation water tanks. The DHT22 sensor is a capacitive sensor type. The working voltage ranges from $3.3 \mathrm{~V}$ to $6 \mathrm{~V}$ with direct current models. The sensing element is made of polymer capacitors with operating humidity ranges from $0 \%$ to $100 \%$ and temperatures from $-40^{\circ} \mathrm{C}$ to $80^{\circ} \mathrm{C}$. The accuracy of DHT22 for humidity and temperature are $\pm 2 \%$ to $\pm 5 \%, \pm 0.5^{\circ} \mathrm{C}$, respectively. Resolution or sensitivity for humidity and temperature are $0.1 \%, 0.1^{\circ} \mathrm{C}$, respectively. The repeatability for humidity and temperature is $0.1 \%, 0.2^{\circ} \mathrm{C}$, respectively. Humidity hysteresis is $\pm 0.3 \%$ with Long-term Stability is $\pm 0.5 \%$ per year. The sensing period is an average of two seconds. Characterization of DHT22 has relative humidity strongly depends on temperature; that is why temperature compensation technology to ensure accurate measurement of RH (DFRobot, China).

The one of temperature sensor used is Dallas digital thermometer also known as DS18B20. The DS18B20 digital thermometer provides 9-bit to 12-bit Celsius temperature measurements. Its communicates over a 1-Wire bus that by definition requires only one data line for communication with a microcontroller. Besides that, it can derive power directly from the data line and eliminate the need for an external power supply. The supply voltage is between \pm 3.0 and $\pm 5.5 \mathrm{~V}$. It operates between $-55^{\circ} \mathrm{C}$ to $125^{\circ} \mathrm{C}$. It has typical accuracies of $\pm 0.5^{\circ} \mathrm{C}$ accuracy from $-10{ }^{\circ} \mathrm{C}$ to $+85^{\circ} \mathrm{C}$.

The sensor used to detect water level and volume of the tank is an ultrasonic sensor HC-SR04 type. This sensor requires $+5 \mathrm{~V}$ DC with quiescent current $<2 \mathrm{~mA}$. Ranging distance of this sensor is $20-4000 \mathrm{~mm}$ with a resolution of $3 \mathrm{~mm}$. There is a single control pin (trig pin). The trig pin is responsible for sending the ultrasonic burst. This pin should be set to high for ten us, at which point the HC-SR04 will send out an eight-cycle sonic burst at $40 \mathrm{kHz}$. After a sonic burst has been sent, the echo pin will go hight (Morgan, 2014).

A board based on the ESP8266 NodeMcu was used. The board is in all respects equivalent and compatible with the Arduino board designed. The $5 \mathrm{~V}, 16 \mathrm{MHz}$ version was employed. It has 16 digital input/output pins, 1 analog inputs, a 10-bit analog-to-digital converter (ADC), an on-board resonator and a voltage regulator. The function of the microcontroller is to request and receive the measurements made by sensor, momentarily power and read its position (which translates to the humidistat set point), and based on this give a signal to the relay to switch an external device on or off.

The light dependent resistor (LDR) sensor module is used for measuring illuminance. The relationship between light intensity and resistance using LDR is presented in Equation (1). Sensors LDR connected to $3.3 \mathrm{~V}$ through a $3.3 \mathrm{~K} \Omega$ resistor; the output voltage of the LDR is shown in Equation (2). From Equation (1) and (2) we obtain light intensity presented in Equation (3). 
$R_{L}=\frac{500}{L}$

$V_{0}=\frac{3.3 \times R_{L}}{\left(R_{L}+3.3\right)}$

$L=\frac{\left(\frac{1650}{V_{0}}-500\right)}{3.3}$,

where:

$R_{L}$.........resistance LDR $(K \Omega)$,

$V_{0}$.........output voltage of the $\operatorname{LDR}(V)$,

L...........Illuminance (lux).

\section{Performance Monitoring System Monitoring}

A preliminary test of system performance is carried out for five days with measurement data sent to the cloud. The process of recording data is done every two seconds. An access point with the internet network is used to send all measurement data. A database that has been equipped with a GUI display is prepared so that the database can be easily accessed for monitoring. An AC power supply is prepared along with its power supply converter to be a power source for this monitoring system.

\section{RESULTS AND DISCUSSION}

The mechanism of the irrigation water tank and bed planting is presented in Fig. 2. Two sets of bed planting measuring $400 \mathrm{~mm} \times 700 \mathrm{~mm}$ will be planted with rice from water from two containers with a capacity of 30 liters. A bed planting and the tank will be designed using the automatic control method, and one more is done manually. The control box of the monitoring system is placed in the water tank by monitoring water level, ambient temperature and humidity, water temperature, and illuminance from light.
Two control box units were prepared to be able to compare the quality of rice cultivation in a controlled manner manually and with a controlled irrigation system designed as an experiment. The recorded data is in the form of environmental data (temperature, RH, sun intensity), and water consumption from aquaculture is monitored online. The monitoring system GUI on the irrigation tank is presented in Fig. 3, which can be accessed online through the website link "http://ttgotomasi.id/ats/ PDPDST/GUI.php”.

\section{Relationship Between Water Level and Tank Volume}

The volume of the irrigation tank will be monitored to be able to find out the water consumption of the rice planting bed (Fig. 4). The sensor with the principle of ultrasonic waves is used to be able to measure the height of the water level inside the irrigation tank. From the height of the water level is then converted using Equation 4, which is found through experimentation into the volume of the irrigation tank. The relationship

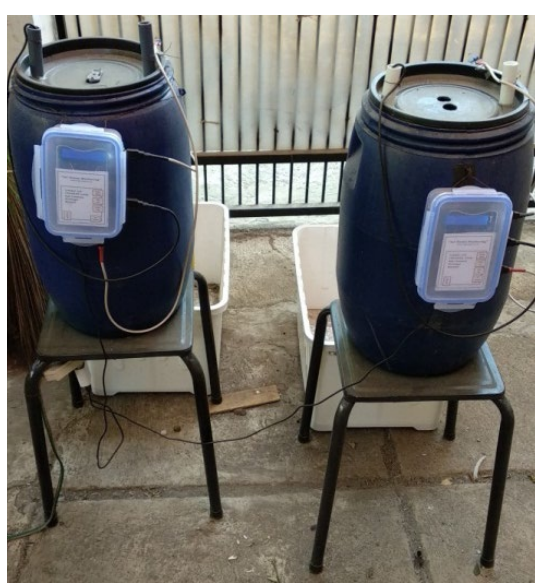

2: Installation of an irrigation tank monitoring system

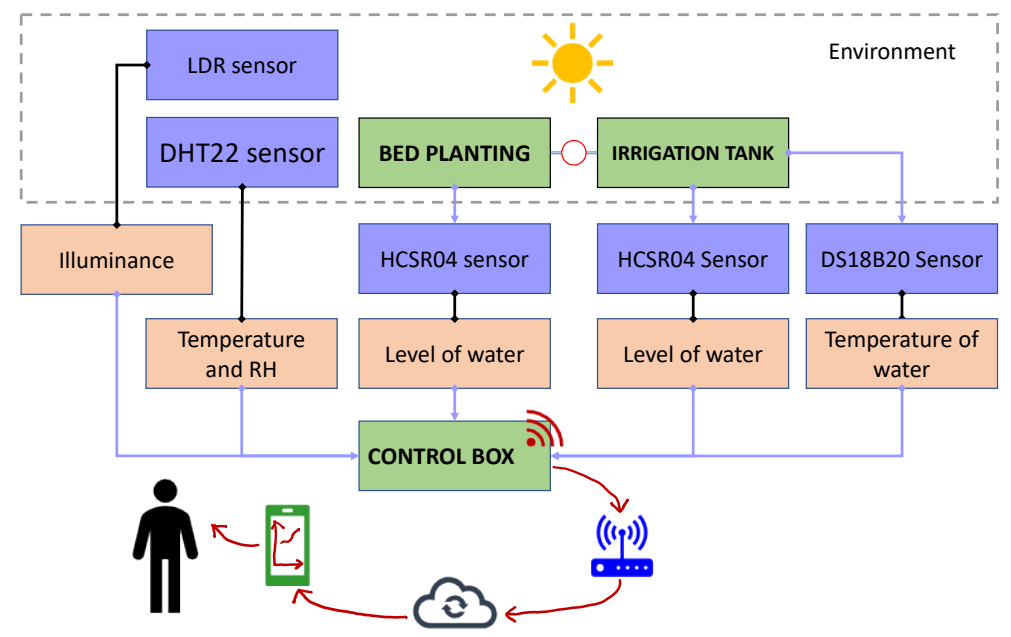

1: Scheme of the monitoring system 


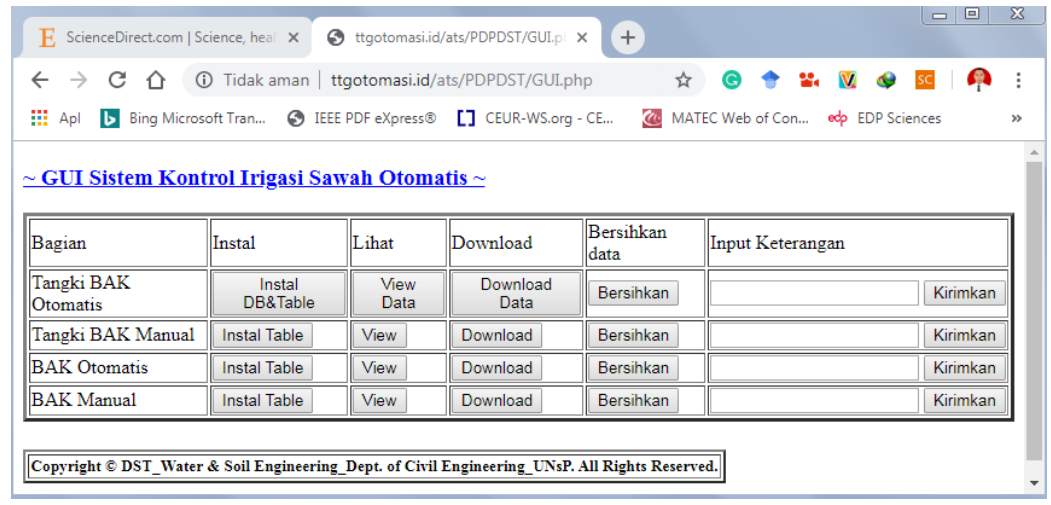

3: GUI irrigation tank monitoring system

between high water level and irrigation tank volume correlates with $99.51 \%$. This shows that the two variables have a close relationship so that it can be used to show the other variables when one of the variables is known.

$V_{T}=0.0691 \times L V L_{W}$,

where:

$V_{T}$........tank volume $(\mathrm{ml})$,

$L V L_{W} \ldots$ hight of water level $(\mathrm{mm})$.

\section{Water Tank Testing}

\section{Automatic Watering System}

The results of data recording from the irrigation tank monitoring system for automatic bed planting are presented in Fig. 5 and Fig. 6. Fig. 5 shows the record of ambient temperature, environmental humidity, and water temperature for five days. Preliminary test results indicate that the DHT22 digital thermometer and humidity sensor and DS18B20 digital thermometer have been able to work to record temperature and humidity accurately. It is in line with the results of several studies that use these sensors and get the quality

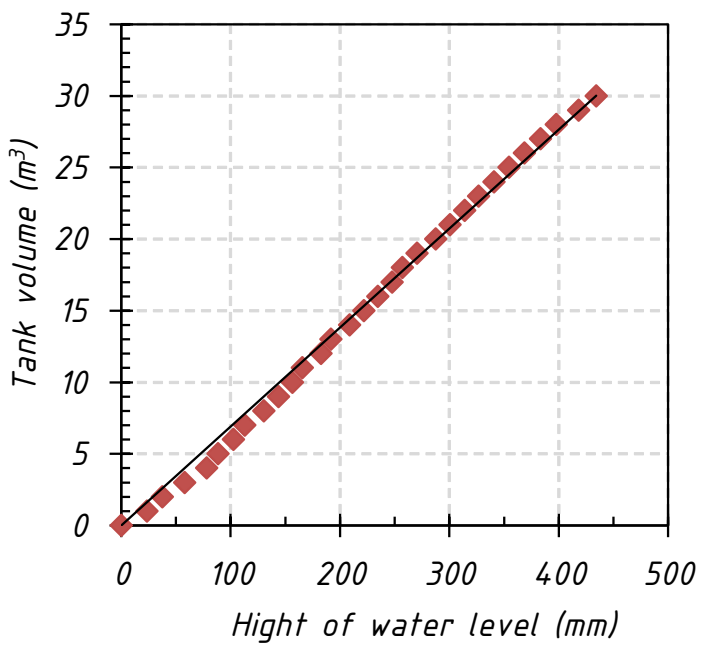

4: Relationship between water level and tank volume of measurement results that are still within normal limits (Hao and Sha, 2012; Vojcinak et al., 2013; Jiaxing et al., 2018; Muangprathub et al., 2019).

This preliminary test showed that the environment around the irrigation tank and bed planting had the highest daily temperature and humidity of $36.86 \pm 2.06^{\circ} \mathrm{C}, \quad 86.94 \pm 4.45 \%$, respectively. The lowest daily temperature and humidity are $22.54 \pm 1.59^{\circ} \mathrm{C}, 34.64 \pm 4.02 \%$, respectively. In general, the highest daily ambient temperature occurs at $12.31 \mathrm{pm}$ to $3.45 \mathrm{pm}$, and the lowest temperature occurs at $11.58 \mathrm{pm}$ to $5.59 \mathrm{am}$. The most moderate daily environmental humidity occurs from $12.11 \mathrm{pm}$ to $3.40 \mathrm{pm}$, and the highest humidity occurs from $11.07 \mathrm{pm}$ to $5.57 \mathrm{pm}$. The average water temperature in the tank has a difference with the ambient temperature of $0.05^{\circ} \mathrm{C}$ during the test.

The light illuminance parameter is needed to determine the solar intensity as an environmental parameter that affects plant photosynthesis. The results of recording environmental temperature with solar intensity for automatic plant beds are presented in Fig. 6. It can be seen that light illuminance is in line with environmental temperature conditions ( $\mathrm{Li}$ and Lou, 2018). It shows that the illuminance of light dramatically affects the environmental temperature conditions around the irrigation tank. Light illuminations in the highest and lowest daily $\mathrm{mV}$ units are $485.41 \mathrm{mV}, 2.22 \mathrm{mV}$, respectively.

\section{Manual Irrigation System}

The results of recording data from the monitoring system of irrigation tanks for manual plant beds are presented in Fig. 7 and Fig. 8. Fig. 7 shows the recording of ambient temperature, environmental humidity, and water temperature for five days. Preliminary test results indicate that the temperature sensors DHT22 and Dallas have been able to work to record temperature and humidity correctly. It is in line with the results of several studies that use these sensors and get the quality of measurement results that are still within normal limits (Hao and Sha, 2012; Vojcinak et al., 2013; Jiaxing et al., 2018; Muangprathub et al., 2019). 


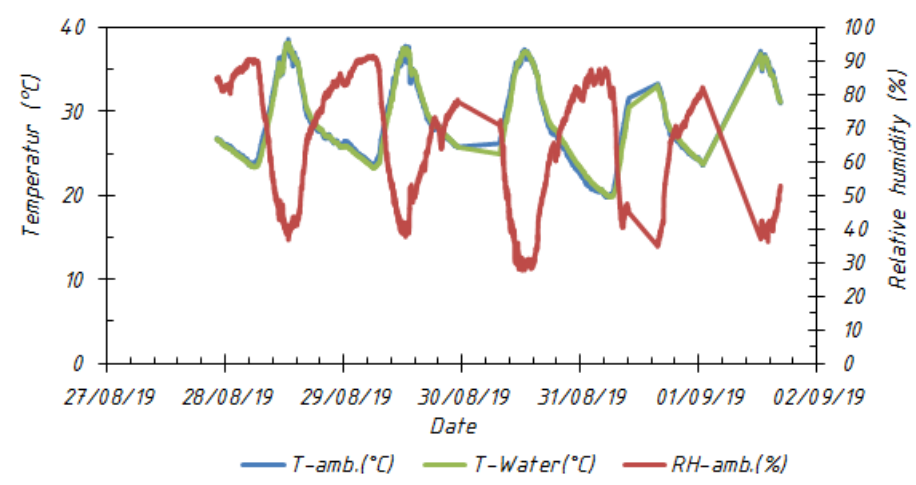

5: Monitoring water temperature, environment and environment in automatic irrigation water tanks

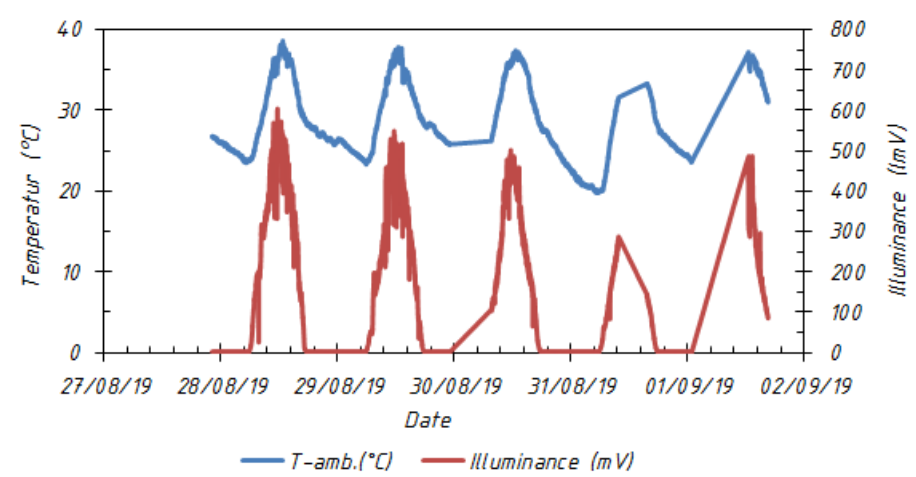

6: Monitoring environmental temperature and solar illuminance in automatic irrigation water tanks

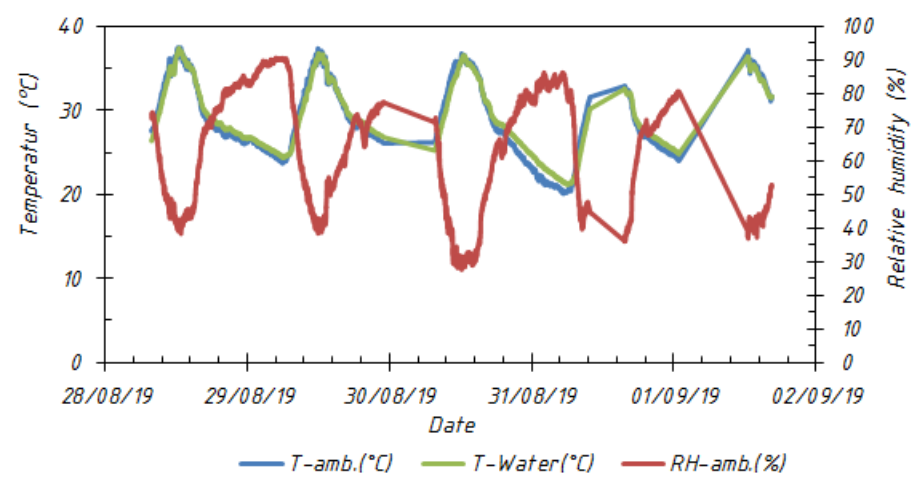

7: Monitoring water temperature, environment and environment in a manual irrigation water tank

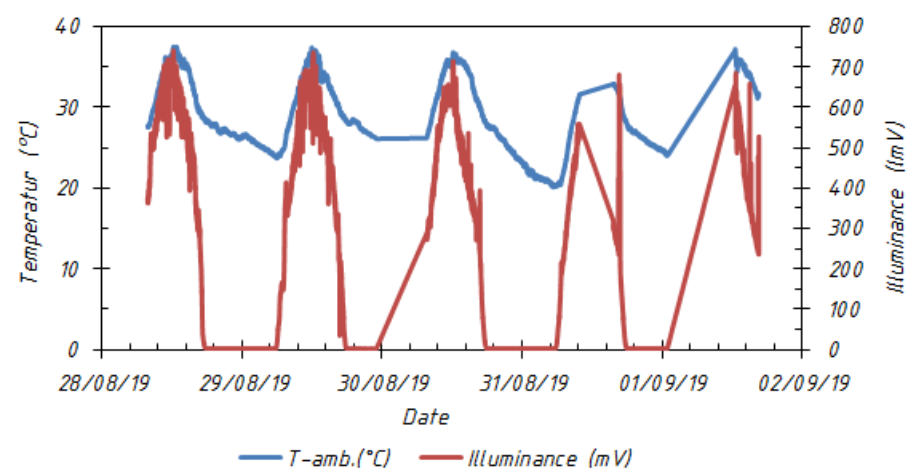

8: Monitoring environmental temperature and solar illuminance in manual irrigation water tanks 
I: Statistical evaluation of monitoring system parameters

\begin{tabular}{lccccc}
\hline \multicolumn{1}{c}{ Parameter of monitoring system } & & Condition & Mean & Sig. Levene statistics & Sig. ANOVA \\
\cline { 1 - 3 } T-amb. $\left({ }^{\circ} \mathrm{C}\right)$ & MIWT $^{*}$ & $29.47 \pm 2.86$ & \multirow{2}{*}{0.002} & 0.823 \\
\hline \multirow{2}{*}{ Relative humidity (\%) } & AIWT $^{* *}$ & $29.04 \pm 2.98$ & & 0.82 \\
\hline \multirow{2}{*}{ T-Water $\left({ }^{\circ} \mathrm{C}\right)$} & MIWT $^{*}$ & $61.01 \pm 4.09$ & \multirow{2}{*}{0.759} & 0.727 \\
\hline \multirow{2}{*}{ Illuminance $(\mathrm{mV})$} & AIWT $^{* *}$ & $62.49 \pm 4.77$ & \multirow{2}{*}{0.014} & 0.056 \\
\hline
\end{tabular}

*MIWT: manual irrigation water tanks

**AIWT: automatic irrigation water tanksw

In this preliminary test showed that the environment around the irrigation tank and bed planting had the highest daily temperature and humidity were $36.36 \pm 1.95^{\circ} \mathrm{C}, 84.86 \pm 4.10 \%$, respectively. The lowest daily temperature and humidity are $23.38 \pm 2.13^{\circ} \mathrm{C}$, $35.44 \pm 4.5 \%$, respectively. In general, the highest daily ambient temperature occurs at 11.57 am to 3.45 $\mathrm{pm}$, and the lowest temperature occurs at $11.32 \mathrm{pm}$ to $6.00 \mathrm{am}$. The most moderate daily environmental humidity occurs from $11.58 \mathrm{am}$ to $3.40 \mathrm{pm}$, and the highest humidity occurs from $11.06 \mathrm{pm}$ to $5.12 \mathrm{am}$. The average water temperature in the tank is different from the ambient temperature of $0.12^{\circ} \mathrm{C}$ during the test.

The light illuminance parameter is needed to determine the solar intensity as an environmental parameter that affects plant photosynthesis. The results of recording ambient temperature with solar intensity for manual plant beds are presented in Fig. 8. It can be seen that light illuminance is in line with environmental temperature conditions (Li and Lou, 2018). This shows that the illuminance of light greatly affects the environmental temperature conditions around the irrigation tank. Light illuminations in the highest and lowest daily $\mathrm{mV}$ units are $711.26 \mathrm{mV}, 2.22 \mathrm{mV}$, respectively.

\section{Statistical Evaluation of the Monitoring System}

The statistical evaluation parameters of the water tank irrigation monitoring system are presented in Tab. I. The highest average ambient temperature found in manual irrigation water tanks is $29.47^{\circ} \mathrm{C}$. The results of the uniformity test of the environmental temperature data using the Levene statistical method were 0.002, which indicates that the ambient temperature of the two irrigation water tanks was homogeneity. ANOVA test results show that the average ambient temperature of the two irrigation water tank conditions is not different. The highest average relative humidity found in automatic irrigation water tanks is $62.49 \%$. The results of the uniformity test of the relative humidity data using the Levene statistical method were 0.759 , which indicated that the relative humidity of the two irrigation water tanks was homogeneous. The ANOVA test results show that the average relative humidity of the two irrigation water tank conditions is not different.

Other parameters such as the highest average water temperature found in automatic irrigation water tanks are $29.99^{\circ} \mathrm{C}$. The result of the uniformity test of water temperature data using the Levene statistical method is 0.014 , which indicates that the water temperature in the two irrigation water tanks is homogeneous. ANOVA test results showed that the average water temperature of the two irrigation water tank conditions was not different. The highest average illuminance found in manual irrigation water tanks was $254.95 \mathrm{mV}$. The result of the uniformity test of the illuminance data using the Levene statistic method was 0.726, which indicates that the illuminance of the two irrigation water tanks was homogeneous. ANOVA test results showed that the average illuminance of the two irrigation water tank conditions was not different.

\section{CONCLUSION}

A test of the irrigation tank monitoring system and its environment has been carried out. The system has been able to record the conditions of temperature and humidity environment, irrigation water temperature, and light illuminance. Sensor measurement data shows that the device can function within normal limits. Any data from the measurement results can already be recorded and sent to the cloud so that it can be monitored online. The database of measurement results can be easily downloaded on the website link that has been prepared. The next work of this research is conducting rice cultivation in bed planting by implementing an irrigation monitoring system that has been designed so that environmental conditions throughout the rice cultivation can be recorded for further analysis to produce a comprehensive conclusion. 


\section{REFERENCES}

BOONJUNG, H. and FUKAI, S. 1996. Effects of soil water deficit at different growth stages on rice growth and yield under upland conditions. 2. Phenology, biomass production and yield. Field Crops Research, 48(1): 47-55.

CARRACELAS, G., HORNBUCKLE, J., ROSAS, J. and ROEL, A. 2019. Irrigation management strategies to increase water productivity in Oryza sativa (rice) in Uruguay. Agricultural Water Management, 222: 161-172.

CEBRO, I. S. and SITORUS, A. 2019. Performance Evaluation Of A Hand Tractor To Climbing Sloping Land. International Journal of Scientific and Technology Research, 8(7): 781-785.

HAO, W. and SHA, S. 2012. Based on TMS320LF2407 Environment Temperature Humidity Detection. Physics Procedia, 25: 1258-1263.

JIAXING, X., PENG, G., WEIXING, W., HUAZHONG, L., XIN, X. and GUOSHENG, H. 2018. Design of Wireless Sensor Network Bidirectional Nodes for Intelligent Monitoring System of Micro-irrigation in Litchi Orchards. IFAC-PapersOnLine, 51(17): 449-454.

LI, D. H. W. and LOU, S. 2018. Review of solar irradiance and daylight illuminance modeling and sky classification. Renewable Energy, 126: 445-453.

MORGAN, E. J. 2014. HC-SR04 ultrasonic sensor. Available at: http://files.s-o.webnode.cz/2000015473ef073fea3/hcsr04.pdf [Accessed: 2020, Sptember 1].

MUANGPRATHUB, J., BOONNAM, N., KAJORNKASIRAT, S., LEKBANGPONG, N., WANICHSOMBAT, A. and NILLAOR, P. 2019. IoT and agriculture data analysis for smart farm. Computers and Electronics in Agriculture, 156: 467-474.

PADHI, N. 2019. Effect of Fertilizer Placement and Methods of Sowing on Rice Productivity. Raipur: Indira Gandhi Krishi Vishwavidyalaya.

PATTNAIK, S., DASH, D., MOHAPATRA, S., PATTNAIK, M., MARANDI, A. K., DAS, S. and SAMANTARAY, D. P. 2020. Improvement of rice plant productivity by native $\mathrm{Cr}(\mathrm{VI})$ reducing and plant growth promoting soil bacteria Enterobacter cloacae. Chemosphere, 240: 124895.

PAUDEL, G. P., KC, D. B., RAHUT, D. B., JUSTICE, S. E. and MCDONALD, A. J. 2019. Scale-appropriate mechanization impacts on productivity among smallholders: Evidence from rice systems in the mid-hills of Nepal. Land Use Policy, 85: 104-113.

SINGH, Y. P., MISHRA, V. K., SINGH, S., SHARMA, D. K., SINGH, D., SINGH, U. S., SINGH, R. K., HAEFELE, S. M. and ISMAIL, A. M. 2016. Productivity of sodic soils can be enhanced through the use of salt tolerant rice varieties and proper agronomic practices. Field Crops Research, 190: 82-90.

THAKUR, A. K., MANDAL, K. G., MOHANTY, R. K. and AMBAST, S. K. 2018. Rice root growth, photosynthesis, yield and water productivity improvements through modifying cultivation practices and water management. Agricultural Water Management, 206: 67-77.

VOJCINAK, P., VAVRLA, T. and KOZIOREK, J. 2013. Using compact system for measuring borehole temperature profiles. IFAC Proceedings Volumes, 46(28): 132-137.

ZHANG, J., LI, Y., ZAHNG, H., DONG, P. and WEN, C. 2019. Effects of Different Water Conditions on Rice Growth at the Seedling Stage. Revista Caatinga, 32(2): 440-448.

Contact information

Dewi Sartika T: dewisartika@nusaputra.ac.id

Rico Sihotang: rico.sihotang@nusaputra.ac.id

Muhamad Muslih: muhamad.muslih@nusaputra.ac.id

Agustami Sitorus: aguslipi122@gmail.com

Oscar Haris: oscar.haris@nusaputra.ac.id

Devianty: devidharma28@yahoo.co.id

Ramayanty Bulan: ramayantybulan@gmail.com 